\title{
Medical confidentiality and the protection of Jehovah's Witnesses' autonomous refusal of blood
}

\author{
Osamu Muramoto Kaiser Permanente Northwest Division Portland, Oregon, USA
}

\begin{abstract}
Mr Ridley of the Watch Tower Society (WTS), the controlling religious organisation of fehovah's

Witnesses $(\mathcal{F} W s)$, mischaracterises the issue of freedom and confidentiality in FWs' refusal of blood by confusing inconsistent organisational policies with actual Biblical proscriptions. Besides exaggeration and distortion of my writings, Ridley failed to present substantive evidence to support his assertion that no pressure exists to conform to organisational policy nor systematic monitoring which compromises medical confidentiality. In this refutation, I present proof from the WTS's literature, supported by personal testimonies of $\mathcal{F W S}$, that the WTS enforces its policy of blood refusal by coercive pressure to conform and through systematic violation of medical confidentiality. Ridley's lack of candour in dealing with the plea of dissident $\mathcal{F W}$ for freedom to make personal and conscientious decisions regarding blood indicates that a serious breach of ethics in the medical care of $\mathcal{Y W}$ s continues. The medical community should be seriously concerned. (Fournal of Medical Ethics 2000;26:381-386)
\end{abstract}

Keywords: Religion; confidentiality; Jehovah's Witnesses; autonomy; blood transfusion

\section{Introduction}

In his reply ${ }^{1}$ to my proposal ${ }^{2}$ for a don't-ask-don'ttell policy on Jehovah's Witnesses' (JWs) personal medical decision making on blood transfusions, $\mathrm{Mr}$ Donald Ridley of the Watch Tower Bible and Tract Society (WTS) has made several serious charges which require further comment. However, before addressing these important issues, I must point out that Ridley resorts to exaggerations and extreme terms to obscure the issues my proposal raises. $\mathrm{He}$ intentionally pushes my discussion to an extreme that does not reflect the reality. For example, he states "Muramoto continues with his theory that people never act on the basis of personal integrity and principles...", "in Muramoto's view people are motivated (coerced) by peer pressure and fear of discipline only", and "Muramoto evidently thinks that no member of any group or community is truly autonomous if the group or community has authority to discipline non-compliant members" (emphasis added). I have never made such extreme statements that cover every member of JWs or the general membership of other organisations. Throughout my writings, ${ }^{3}$ I have presented the situation of "dissident" JWs who conscientiously disagree with the blood policy. They are of course a minority of the JW membership. Ridley even turns my argument completely around by saying " $\mathrm{Mu}-$ ramoto's arguments ignore the elements of individual conscience". It is incomprehensible how Ridley came to such a distorted conclusion when the whole point of my writings is precisely to protect the freedom of conscience of individual JW patients.

Ridley also misrepresents my arguments by stating "it is not readily apparent how exegetical differences between Muramoto and Jehovah's Witnesses advance medical ethical discourse". Here he misrepresents my argument as a difference between my Biblical interpretation and that of JWs. Yet I have repeatedly mentioned in this series of articles ${ }^{3}$ that the difference is between dissident JWs and the controlling WTS. But that is not the ethical issue dissident JWs are raising. The issue is the course the WTS follows in controlling the personal medical decision making of those JWs who have other views of the Bible regarding the medical use of blood. It is actually a conspicuous ethical problem that a religious organisation controls personal, confidential and potentially life-saving decision making of individual members in medical care based on "exegetical differences". Whether Ridley really cannot comprehend this important ethical issue or only pretends to miss the point in order to obscure the real issue is unclear. In either case the issue is worth "medical ethical discourse" and I will expand on it in this response.

\section{Personal conscience or hypocrisy?}

Ridley tries to dismiss my proposal by claiming that a don't-ask-don't-tell policy promotes hypocrisy by hiding the discrepancy between public and private actions. Ridley wrote that "Jehovah's Witnesses believe that God sees everything we do regardless of whether other humans are aware of our actions". Thus, in his words, Jehovah's Witnesses' decision making is seen by God and $\mathrm{He}$ is the final judge. That is precisely my point: that the matter of making a choice about blood transfusions should rest as a matter between the conscience of the persons needing them and their God, without the monitoring, intervention or sanction of an organisation.

It is also misleading for Ridley to speak of JWs being encouraged by my proposal to act privately 
"in a manner they publicly declare to be wrong", and to say that my proposal "trivialises the personal religious convictions of Jehovah's Witnesses by suggesting they ignore their belief that the love of God means that they observe his commandments". The blood policy was not originated from the "personal religious conviction" of each JW; the complex conglomerate of rules for medical use of blood were elaborated by the leadership and handed to JWs for following. Some JWs conscientiously believe that God has not, in the Bible or elsewhere, forbidden blood transfusions, and that to accept a life-saving blood transfusion is not to disobey God's commandments. Just as the ruling leadership has conscientiously decreed that transfusion of certain blood products does not violate God's commandments so these JWs conscientiously believe other blood products may be transfused for life-saving purposes without violating God's commandments. They do not "publicly declare" their views because of the draconian punishments meted out by their organisation and its appointed elders.

A don't-ask-don't-tell policy is to be considered only when a person's freedom of action conflicts with inordinate peer pressure. There is no inherent moral judgment in such a policy. Whether it enhances moral behaviour or not depends on how such a policy is implemented. I would ask Mr Ridley whether the WTS's policy change in 1983 to leave oral sex between marriage partners as a personal conscientious matter ${ }^{4}$ promoted hypocrisy. His answer should be no. If someone in a bedroom or hospital room chooses an action that he or she believes is not prohibited by God's commandments, whether it is engaging in oral sex or receiving plasma (a blood component prohibited by WTS), then silently keeping that action private is not hypocrisy. Although the oral sex issue seems trivial compared to the blood issue, sexual immorality is prohibited in Acts $15: 29^{5}$ in parallel with eating blood; whether oral sex constitutes sexual immorality was a subject of discussion in JW literature, as much as whether transfusion of plasma constitutes eating blood. There are many parallels between these two specific actions that the WTS prohibits.

\section{Freedom of choice or organisational mandate?}

Ridley uses the scriptural phrase "abstain from blood" as justification and validation of the organisational rulings, but he fails to address how to put this injunction in a contemporary context. His argument jumps from such religious concepts as God, the Bible and first century Christians to a complex set of organisational rules of modern medical technology without regard to how such complex rules are related to the religious concepts. He ignores the argument raised by the dissident JWs who question the scriptural basis for the complex, equivocal and arbitrary division of acceptable and unacceptable fractions and procedures and for the entire doctrine of refusal of blood transfusions (as distinct from eating blood). Indeed, to those dissident JWs, the decision to accept or refuse blood is not about God, the Bible or first century Christians, but about which blood fraction a JW patient chooses, as compared to which blood fractions the WTS approves. As long as the WTS policy forbids certain blood fractions and allows others, as opposed to abstention from all blood products, it contradicts its own Bible interpretation, "abstaining from blood means not taking it into our bodies at all". ${ }^{6}$ This contradiction alone causes certain JWs to arrive at the conclusion that the policy is not based on God or the Bible.

\section{Military service}

As an experienced official of the WTS, Ridley knows that when the organisation "adjusts" any part of its policy, the majority of JWs will submit to it regardless of their personal choice. That would be true of virtually any addition to, or any subtraction from, the presently accepted views. Such a change recently happened regarding the policy on "alternative service" to military duties. Until 1995, the WTS prohibited JW men not only from joining the military but from voluntary alternative service such as hospital work or other civilian duties the government provided for conscientious objectors. The WTS reasoned that, as a "substitute," such service was the equivalent of military service and thus must be refused. While this policy was in force, it is a documented fact that letters from the branch offices of major countries to the governing body of JWs frankly acknowledged that, on the whole, the young men in their countries did not understand the basis for the WTS's position in this matter, but were willing to go to prison in order to conform to it. $^{7}$ Young Witnesses by the thousands did that for about fifty years. The new policy allows the issue to rest within the realm of personal conscience. Ridley introduces the phrase "mind control" (a term I did not use in my articles), but it is not necessary to label a situation when the facts speak for themselves. Thousands of young men chose to follow the now-defunct policy and spend time in jail. They were not overtly coerced into doing so. But the majority clearly did not so choose because of being firmly convinced in their own minds and hearts as to the rightness or reasonableness of the policy. The letters from the organisationally appointed principal men in their countries make that clear. Without employing terms such as "mind control," the evidence is there that they felt pressure to conform.

The medical community should learn from our debate that a more serious ethical problem than imprisonment for refusing alternative military service exists today in the medical care of JWs. Should the medical community dismiss this as a mere internal theological issue, as Ridley portrays it, when human lives are being lost due to an organisational policy that most JWs do not comprehend and where pressure to conform is backed up by threat of excommunication? Ridley compares the controlling influence of the WTS on JWs' decision making with outside influences such as TV, newspapers and magazines. This analogy is flawed 
because the recipient of other outside influences is not pressured to accept views as God's, sent through his divine channel, and is not punished if he or she acts against that influence.

In reference to "mind control", Ridley also claimed that coercive manipulation "as applied to religious movements lacked any scientific foundations" by citing the 1987 internal memo of the American Psychological Association (APA) ${ }^{8} \mathrm{How}-$ ever, the memo, addressed from the Board of Social and Ethical Responsibility for Psychology (BSERP) to the members of the Task Force on Deceptive and Indirect Methods of Persuasion and Control, expresses no official rejection of mind control theories. It simply rejects a report prepared by the task force due to lack of proper methods. The memo actually concluded that "after much consideration, BSERP does not believe that we have sufficient information available to guide us in taking a position on this issue". This conclusion is far from Ridley's assertion that coercive manipulation is "a theory roundly debunked by the scientific community over a decade ago". The board of the APA merely stated that the information is insufficient on this issue. Admittedly, the issue of "mind control" is quite controversial, requiring further research, but it has not been "roundly debunked" as Ridley claims. For example, the widely used diagnostic criteria of mental disorders from the American Psychiatric Association (DSM-IV) lists "brainwashing, thought reform, or indoctrination while captive" as examples of states of dissociation due to prolonged and intense coercive persuasion.

\section{Shunning practice as organisational coercion}

Ridley repeats David Malyon's argument ${ }^{10}$ that al JWs joined the religion freely with full understanding of the blood policy. Here Ridley ignores the hundreds of thousands who are members because they were raised by JW parents and baptised as minors. They were indoctrinated from childhood into the religion with minimal exposure, if any, to critical views. It is sufficient to point out that the WTS strongly discouraged JW youths from seeking higher education until 1992, that they are today strongly discouraged from participating in internet forums, and that JW children are trained to recite their position on blood to doctors and judges. Where is the free will and full understanding of doctrine for these next generation JWs?

Ridley implies that leaving the religion has little social cost and that disfellowshipping of members pressures no one to conform to the blood policy. $\mathrm{He}$ states that it is an "indisputable fact" that "those who wish to leave the religion or choose to become inactive non-participants readily do so". He further claims that disfellowshipping severs only spiritual ties and that "non-spiritual associations are not terminated". The fact is that there are thousands of former JWs enduring total shunning by their JW family members who believe this is the only faithful course for JWs. Contrary to Ridley's insistence, social association is banned. Even former governing body member Raymond Franz was disfellowshipped on the charge of eating lunch with his employer who had disassociated himself from the congregation, as reported in a Time magazine article. ${ }^{11}$

What are the underlying teachings about the shunning of disfellowshipped members? Ridley used the 1981 Watchtower magazine ${ }^{12}$ I had quoted in an attempt to show "family ties" are not terminated by disfellowshipping. A careful reading of the Watchtower instruction shows that the "family ties" that are not affected by disfellowshipping are merely the genetic and legal relationships of family members. Since Ridley gives a wrong impression to readers regarding these coercive practices, I shall clarify the official WTS instructions.

In the 1988 Watchtower article quoted by Ridley, ${ }^{13}$ the following paragraph regarding family relationship appears:

"God certainly realizes that carrying out his righteous laws about cutting off wrongdoers often involves and affects relatives. As mentioned above, when an Israelite wrongdoer was executed, no more family association was possible. In fact, if a son was a drunkard and a glutton, his parents were to bring him before the judges, and if he was unrepentant, the parents were to share in the just executing of him, 'to clear away what is bad from the midst of Israel'. (Deuteronomy 21:18-21) You can appreciate that this would not have been easy for them. Imagine, too, how the wrongdoer's brothers, sisters, or grandparents felt. Yet, their putting loyalty to their righteous God before family affection could be lifesaving for them."

In short, the WTS compares the current disfellowshipping practice to the execution of wrongdoers by the Israelites. The article also states: "In various serious matters, willful violators were executed .... When that happened, others, even relatives, could no longer speak with the dead lawbreaker". Then the reason "family ties" continue is explained thus: "Cutting off from the Christian congregation does not involve immediate death, so family ties continue". In other words, the WTS teaches JWs to treat disfellowshipped relatives as if they were dead by execution, but because they are physically alive genetic and legal ties as a family member continue.

When an immediate family member living in the same household is disfellowshipped, legal family relationships continue. However, the disfellowshipped member is not permitted to participate in any religious activities such as leading Bible studies and prayer or discussing doctrinal issues. For a Christian household, can this be considered "normal family affections and dealings"? It is true that the WTS does not recommend immediate divorce from disfellowshipped mates. However, if a JW man was disfellowshipped for dissenting from the WTS's blood policy and he tried to explain his views to his wife, what would happen? No such intimate discussion is permitted even within the immediate family circle. The WTS has provided a 
means for the wife to separate from the husband without violating the WTS prohibition against divorce except for adultery: it is called "absolute endangerment of spirituality". ${ }^{14}$ Under this policy, an orthodox JW can obtain a legal separation from the dissenting JW who would discuss his views. This is exactly what happened to Wayne Rogers, a California second-generation JW, who expressed his conscientious disagreement with the blood policy in personal electronic mail. His JW wife discovered the mail and showed it to the congregation elders. As a result, Rogers was disfellowshipped in January 1999 and his wife obtained a separation. His testimony about disfellowshipping and separation from family vividly illustrates the tragedy of shunning practised by JWs. ${ }^{15}$

For relatives who are not in the immediate family circle and for JW friends, all personal and social contacts are terminated except for necessary business contacts. The official instruction states: "Discussion of business matters with him or contact on the job might be necessary, but spiritual discussions and social fellowship would be things of the past". ${ }^{16}$ The shunning practice of JWs involves every sort of family and social activity; it has caused irreparable psychological trauma in many JW households. In fact, shunning is one of the most painful traumas many former JWs have to live with throughout their lives. For details, refer to testimonies collected on the web site of former JWs. ${ }^{17}$

How does this shunning practice work to coerce the members to comply with the organisational policies? The Watchtower article cited above discussed the desirability of cutting off association because of the results it achieves. ${ }^{18}$ It quoted a JW as saying: " 'Cutting ourselves off completely from all association with [my disfellowshipped sister] Margaret tested our loyalty to Jehovah's arrangement. I gave our family opportunity to show that we really believe that Jehovah's way is best.'-Lynette." Later it described "Margaret's" reaction to being shunned: "'If you had viewed the disfellowshipping lightly, I know that I would not have taken steps toward reinstatement as soon as I did. Being totally cut off from loved ones and from close contact with the congregation created a strong desire to repent. I realized just how wrong my course was and how serious it was to turn my back on Jehovah." "19 Such testimonies published in this official Watchtower magazine speak for themselves in showing how the shunning practice works to achieve conformity to "Jehovah's arrangement" as determined by the WTS.

In summary of this section, in response to Ridley's assertion that "Muramoto repeatedly refers to the 'enormous' pressure to conform that, according to Muramoto, results from the Witnesses' Bible-based practice of disfellowshipping .. disfellowshipping requires shunning and severance of personal ties with family members-another misrepresentation of the facts", I have presented the facts stated in the official instructions by the WTS and the testimonies of JWs themselves. Indeed the facts speak for themselves that the cur- rent shunning practice of the WTS can coerce JWs to refuse blood transfusions even at risk of their death.

\section{Freedom of association or right of organisation?}

Defending the coercive practice of disfellowshipping and shunning, Ridley justifies the restriction of freedom of choice in the medical care of JW members. He states that John Stuart Mill's statement on free society does not apply to the JW community because it applies to civil government, notwithstanding the qualification I quoted in Mill's statement, "whatever may be its form of government". What Ridley fails to tell is that the WTS teaches that the "theocratic government" started in the Hebrew nation in $1513 \mathrm{BCE}$ and continues in the form of "modern-day theocratic organisation" such as the WTS. ${ }^{20}$ In its official magazine the WTS is equated to "a separate nation" and "a theocratic land". ${ }^{21}$ What is inescapably hypocritical is for Malyon and Ridley to use Mill's statement to demand freedom for their organisation in the larger human community, while they simultaneously promote among the JW community a "government" which denies Mill's freedom to pursue personal values.

Ridley's quotation regarding "nonconformists" who may "threaten the common welfare" of a community would apply only if the JW community is one requiring total conformity and not allowing for exercise of personal, individual conscience. Furthermore the "threat" to the common welfare is not demonstrated, simply alleged. Allowing the exercise of personal, individual conscience in the matter of alternative military service clearly is deemed not to threaten the common welfare of JWs. Why, then, would the exercise of personal, individual conscience in a matter such as an autologous blood transfusion threaten that common welfare? The only "threat" seems to be to the absolute authority of the JW leadership and its pervasive control over the decisions of individual JWs.

\section{Respect for privacy or organisational monitoring?}

Ridley adamantly denies the church organisation's systematic monitoring of JW patients' private lives by saying, "Muramoto's proposals to rein in allegedly intrusive elders and to educate individual Witnesses about their privacy rights address nonexistent problems. Witness elders and hospital liaison committee members are not commissioned, explicitly or otherwise, to pry into the private affairs of individual Witnesses", "Muramoto provides no authority for these statements". The striking fact is that Ridley, as a lawyer himself representing the WTS, never retracts or denounces the widely publicised policy published by the WTS in 1987 to encourage JW hospital workers to breach medical confidentiality. ${ }^{22}$ The article used a hypothetical but typical JW hospital worker, "Mary", who incidentally obtained confidential medical information that 
a fellow JW woman received an abortion in the hospital where Mary worked. The article encouraged Mary to breach medical confidentiality by revealing this information to the congregation elders, even if such an action is illegal in many jurisdictions. There has never been any WTS publication to reverse or retract this notorious policy. Ridley is fully aware of this policy, which I repeated in two parts of my papers, yet he provides no evidence or documentation to support his assertion that this is one of the "nonexistent problems" I am addressing. He reviews the issue of medical confidentiality in his reply and has an opportunity to respond, yet he never addresses this policy. The distinct absence of a response from the WTS legal counsel indicates that, even if he asserts absence of patient monitoring by peers, the policy to encourage sometimes illegal disclosure of medica confidentiality is still in force in the JW community.

Recently I obtained a copy of an internal letter issued by the WTS and circulated among hospital liaison committee members showing that the "hospital visitation group" was instructed to "verify" that the patient it visits has already talked with medical staff and told them that he or she needs to avoid blood transfusion. ${ }^{23}$ Hospital visitation groups are also instructed to contact the local hospitals on a regular basis to see if any JW patients are hospitalised so that they may visit all JW patients. Although the group's primary goal is not to monitor JW patients, but to give "pastoral care", none the less, such systematic visitation and "verification" of private medical information such as blood refusal inevitably results in systematic monitoring and, in essence, prying into the member's private medical decision making.

The following testimony shows this practice as a personal experience of a JW elder. ${ }^{24}$

"In my congregation a hospitalized congregation publisher [a JW active in preaching] received an unexpected visit from a Hospital Visitation Committee member who observed that he was receiving a blood transfusion. This confidential information was then reported to the presiding overseer and a judicial committee was convened while the man was still in the hospital. The publisher was promptly disfellowshiped. The three elders felt there was nothing he could do to demonstrate repentance since the blood had already been transfused. About six months later the disfellowshiped man applied for reinstatement and I served on the committee that heard his plea. I can still recall the look on this poor man's face as he wept and begged us to reinstate him so that he would not die out of favor with God. We reinstated him that day and a few weeks later he lost his fight with leukemia."

\section{Conclusion}

Mr Ridley, an official representative of the WTS, argues in his reply that JWs cannot be accorded the liberty to make a personal and confidential medical decision to receive a prohibited blood fraction because allowing for such a conscientious decision is tantamount to promoting hypocrisy. He further states that the WTS has the right to deny JWs' personal freedom to choose medical treatment on the basis of personal conscience and to keep such decisions confidential because this is necessary to protect the "common welfare" of "ordered society". Since he denies the presence of coercive practices and invasion of patient's privacy, I have presented further evidence that serious ethical violations are currently used to enforce the blood policy. Obviously Mr Ridley's official statement requires further scrutiny and consideration by the medical community at large. Further wide ranging discussions on this subject from the medical, ethics and religious communities are vitally important. For my part I believe doctors should inform all JW patients who refuse life-saving blood transfusions that there is internal disagreement within the Jehovah's Witness community about whether such refusal is required by God's commandments, and that the patient is at liberty to make a conscientious decision to accept such a transfusion in total medical confidentiality.

\section{Disclaimer}

Views and opinions expressed herein are personal and do not reflect those of Kaiser Permanente and Northwest Permanente PC.

\section{Acknowledgement}

I thank many current and former Jehovah's Witnesses who provided me with valuable documents and discussion, which formed the basis of this paper. Unfortunately, their names cannot be disclosed publicly due to fear of retribution by the religious organisation.

Osamu Muramoto, MD, PhD, is a member of the Regional Ethics Council at Kaiser Permanente Northwest Division and a neurologist at Northwest Permanente PC, Portland, Oregon, USA. Address correspondence to: Kaiser Permanente Interstate Medical Office East, 3550 N Interstate Avenue, Portland, Oregon 97227 USA. E-mail:muramotosa@kpnw.org

\section{References and notes}

1 Ridley DT. Jehovah's Witnesses' refusal of blood: obedience to scripture and religious conscience. Fournal of Medical Ethics 1999;25:469-72

2 Muramoto O. Bioethics of the refusal of blood by Jehovah's Witnesses: part 3. A proposal for a don't-ask-don't-tell policy. fournal of Medical Ethics 1999;25:463-8.

3 Muramoto O. Bioethics of the refusal of blood by Jehovah's Witnesses: part 1. Should bioethical deliberation consider dissidents' views? Fournal of Medical Ethics 1998;24:223-30. Muramoto O. Bioethics of the refusal of blood by Jehovah's Witnesses: part 2. A novel approach based on rational non-interventional paternalism. Fournal of Medical Ethics 1998; 24:295-301.

4 Anonymous. Honor godly marriage. The Watchtower 1983 Mar 15: $30-1$

5 The Bible. Acts 15:29.

6 Anonymous. Godly respect for life and blood. The Watchtower 1969 Jun 1: 327

7 Franz R. In search of Christian freedom. Atlanta: Commentary Press, 1991: 259-68. Franz R. Crisis of conscience [3rd ed]. Atlanta: Commentary Press, 1999: 121-31. A former member of the governing body, Raymond Franz, shows quotations from the 1978 letters sent by branch committee members of 
major countries which questioned the scriptural basis fo refusal of alternative service. Note the similarity to the curren internal controversy on the scriptural basis of refusal of blood.

8 Board of Ethical and Social Responsibility for Psychology. Memo to the members of the Task Force on Deceptive and Indirect Methods of Persuasion and Control. Washington, DC: American Psychological Association, 1987 May 11.

9 American Psychiatric Association. Diagnostic criteria from $D S M-I V$. Washington, DC: American Psychiatric Association, 1994: 232

10 Malyon D. Transfusion-free treatment of Jehovah's Witnesses: respecting the autonomous patient's motives. Fournal of Medical

11 Ostling RN. Witness under persecution. A secretive and apocalyptic sect shuns a former leader. Time 1982 Feb 22: 66

12 Anonymous. If a relative is disfellowshiped ...The Watchtower 1981 Sept 15: 26-31 at 28 .

13 Anonymous. Discipline that can yield peaceable fruit. The Watchtower 1988 April 15:26-31 at 28 .

14 Anonymous. When marital peace is threatened. The Watchtowe 1988 Nov 1: $20-5$ at 22 .

15 Rogers W. The Wayne Rogers story. Available on line at: http:/ www.ajwrb.org/wayne.htm
16 Anonymous. Disfellowshiping - how to view it. The Watchtower 1981 Sept 15: $20-6$ at 24

17 Beacon Light for Former Jehovah's Witnesses (available on line at http://www.xjw.com) has several articles on shunning, including a testimony of a former JW who could never see his JW mother after disfellowshipping until her funeral (http:// www.xjw.com/ron-mom.html), and another testimony about a devout JW mother who was disfellowshipped after decades of loyal adherence for refusing to shun her only son (http:/ www.xjw.com/rawe-df.html)

18 See reference 13: 26 .

9 See reference 13: 30. Jenow's victorious organisation. The Watchtower 1979 Mar 1: 12.

21 Anonymous. Jehovah rules - through theocracy. The Watchtower 1994 Jan 15: 14.

22 Anonymous. "A time to speak"- when? The Watchtower 1987 Sept 1: 12 .

23 Watch Tower Society. Regulations of the visitation group of the patients. This is a letter sent to the members of the hospital liaison committee in October, 1993. A copy in Spanish can be viewed online at: http://www.ajwrb.org/visitation.htm

24 This testimony is available on line at: http://www.ajwrb.org/ letest.htm

\section{News and notes \\ Journal of Medical Ethics - http://www.jmedethics.com}

Visitors to the world wide web can now access the Fournal of Medical Ethics either through the BMJ Publishing Group's home page (http:/ www.bmjpg.com) or directly by using its individual URL (http://www.jmedethics.com). There they will find the following:

- Current contents list for the journal

- Contents lists of previous issues

- Members of the editorial board

- Subscribers' information

- Instructions for authors

- Details of reprint services
A hotlink gives access to:

- BMJ Publishing Group home page

- British Medical Association website

- Online books catalogue

- BMJ Publishing Group books.

The web site is at a preliminary stage and there are plans to develop it into a more sophisticated site. Suggestions from visitors about features they would like to see are welcomed. They can be left via the opening page of the BMJ Publishing Group site or, alternatively, via the journal page, through "about this site" 